\title{
Absence of Interactions between Denosumab and Warfarin in Women with Osteoporosis
}

\author{
Vincenzo Polimeni ${ }^{1}$, Gianluca Sottilotta ${ }^{2, *}$, Fabiola Branca $^{3}$, Nadia Mammone ${ }^{4}(\mathbb{D}$ and \\ Antonio Panuccio ${ }^{1}$ \\ 1 Unità Operativa Complessa Recupero e Riabilitazione, Grande Ospedale Metropolitano di Reggio Calabria, \\ 89100 Reggio Calabria, Italy; vincenzopolimenirc@gmail.com (V.P.); anto.pan@libero.it (A.P.) \\ 2 Unità Operativa Semplice Dipartimentale Microcitemie Emostasi e Trombosi, Grande Ospedale \\ Metropolitano di Reggio Calabria, 89100 Reggio Calabria, Italy \\ 3 Clinica Nova Salus, 89010 Villa San Giovanni, Italy; brancafabiola@gmail.com \\ 4 Istituto di Ricovero e Cura a Carattere Scientifico Centro Neurolesi Bonino-Pulejo, 98100 Messina, Italy; \\ nadia.mammone@irccsme.it \\ * Correspondence: gianluca.sottilotta@virgilio.it; Tel.: +39-0965-393841
}

Received: 17 September 2018; Accepted: 23 October 2018; Published: 26 October 2018

\begin{abstract}
The monoclonal antibody denosumab reduces bone resorption. Warfarin is an oral anticoagulant used in the prevention and treatment of thrombosis. To date, there have been no studies on the interaction between warfarin and denosumab. The aim of the present study was to assess the maintenance of the Prothrombin Time International Normalized Ratio (INR) in the therapeutic range (TTR) in women under treatment with warfarin and denosumab, in order to evaluate the pharmacological interference of denosumab. No variations of the median TTR were found after undergoing treatment with denosumab: this shows that the intake of denosumab does not require additional checks in anticoagulated patients.
\end{abstract}

Keywords: osteporosis; denosumab; warfarin

\section{Introduction}

Osteoporosis is a systemic disease of multifactorial etiology, characterized by a reduction in bone mass and deterioration of the microarchitecture of the bone tissue, which results in increased fragility and therefore an increased risk of fracture [1]. Among the many therapeutic options for osteoporosis treatment, an important role is played by the use of the denosumab monoclonal antibody (Prolia, Amgen). In normal bone remodeling, the amount of bone reabsorbed by osteoclasts is equivalent to the amount of bone formed by osteoblasts, which is due to the interaction between the Receptor activator of nuclear factor-kB (RANK) system (receptor expressed on the osteoclast surface) and Rank-ligand (RANKL) (cytokine produced by osteoblasts to stimulate bone resorption). Denosumab has been designed to bind with high affinity and specificity to RANKL, thus preventing the activation of its RANK receptor and reducing the formation and activity of osteoclasts. This limits the loss of bone substance by performing an anti-rheororbitive action [2,3]. Warfarin (Coumadin, Bristol-Myers Squibb) is a coumarinic anticoagulant intended for the prevention of cardioembolic stroke and for the treatment and prevention of venous thromboembolism. It works by inhibiting the synthesis of vitamin $\mathrm{K}$ dependent coagulation factors; its anticoagulant effect is measured by monitoring the Prothrombin Time International Normalized Ratio (INR), which should be maintained in predetermined and defined therapeutic ranges intervals. Many medications can affect the patient's response to warfarin, through pharmacodynamic or pharmacokinetic mechanisms [4]. Some studies have also observed seasonal variations in warfarin concentrations in the absence of other causes. To the 
best of the authors' knowledge, no scientific work has evaluated the possible interactions between warfarin and denosumab. The purpose of the present study was to assess the INR time maintenance in the therapeutic range (TTR) in a group of women already treated with warfarin, who began taking denosumab, in order to assess any pharmacological interference consequent to the assumption of denosumab [5-8].

\section{Material and Methods}

Six women (mean age 76.2; range 73-86), already under treatment with warfarin $5 \mathrm{mg}$, for atrial fibrillation (4 pts.), venous thrombosis (1 pt.), and biological valvular prosthesis (1 pt.), started treatment with denosumab $60 \mathrm{mg}$, with 1 vial administered subcutaneously every six months. The clinical features of the patients are summarized in Table 1 . The average observational period of patients during treatment with both drugs was 356.1 days (range 144-699). Patient 1 experienced fracture of the left foot and of the first lumbar vertebra. The INR trend in terms of TTR was compared to periods of intake of warfarin of equal duration, before undertaking the treatment with denosumab. The results were compared to those of 12 women of the same age, undergoing therapy with warfarin for the same indications and for the same study period as the enrolled patients, but without denosumab treatment. The analysis of the TTR before and during treatment with denosumab involved the distribution of values in patients and controls and was implemented by calculating the median of the distribution as well as the 25th and 75th percentiles. Due to the limited number of recruited patients, an extensive statistical validation could not be carried out. However, given the encouraging results achieved, the cohort will be extended in the near future and the differences in the INR values before and under Prolia will be statistically assessed; possible correlations with age, menopausal age, and lumbar and femoral bone mineral density will also be investigated.

Table 1. Summary of patients' clinical characteristics.

\begin{tabular}{|c|c|c|c|c|c|c|c|c|}
\hline Patient & Age & $\begin{array}{l}\text { Menop. } \\
\text { Age }\end{array}$ & BMI & $\begin{array}{c}\text { Lumbar } \\
\text { BMD }\end{array}$ & $\begin{array}{c}\text { Femoral } \\
\text { BMD }\end{array}$ & Other Concomitant Drugs & $\begin{array}{c}\text { Reason for } \\
\text { Anticoagulation }\end{array}$ & $\begin{array}{c}\text { Other } \\
\text { Diseases }\end{array}$ \\
\hline Patient 1 & 76 & 53 & 26 & -2.1 & -0.77 & Bisoprolol, Irbesartan & $\begin{array}{c}\text { Atrial } \\
\text { Fibrillation }\end{array}$ & Hypertension \\
\hline Patient 2 & 80 & 51 & 19 & -3.37 & -2.59 & $\begin{array}{c}\text { Bisoprolol, Digoxin, } \\
\text { Furosemide, Insulin, } \\
\text { Lansoprazole, Ramipril }\end{array}$ & $\begin{array}{l}\text { Atrial } \\
\text { Fibrillation }\end{array}$ & $\begin{array}{c}\text { Diabetes, } \\
\text { Hypertension }\end{array}$ \\
\hline Patient 3 & 75 & 48 & 16 & -3.6 & -3.2 & None & $\begin{array}{l}\text { Deep Venous } \\
\text { Thrombosis }\end{array}$ & None \\
\hline Patient 4 & 81 & 47 & 25 & -3.2 & -0.87 & Acetylsalicylic acid, Atenolol & $\begin{array}{l}\text { Atrial } \\
\text { Fibrillation }\end{array}$ & $\begin{array}{l}\text { Ischemic } \\
\text { Heart } \\
\text { Disease }\end{array}$ \\
\hline Patient 5 & 89 & 54 & 17 & -4.38 & -2.5 & $\begin{array}{c}\text { Furosemide, } \\
\text { Hydrochlorothiazide/Valsartan }\end{array}$ & $\begin{array}{l}\text { Biological Valve } \\
\text { Prosthesis }\end{array}$ & None \\
\hline Patient 6 & 70 & 45 & 32 & -2.84 & -3.25 & Digoxin & $\begin{array}{c}\text { Atrial } \\
\text { Fibrillation }\end{array}$ & None \\
\hline
\end{tabular}

BMI: body mass index, BMD: bone mineral density.

\section{Results}

The analysis of the TTR in the six patients treated with warfarin and denosumab showed an increase from $63 \%$ to $70 \%$ of the median TTR after the beginning of denosumab treatment and an increase of the 25th percentile from $60 \%$ to $68 \%$ (Figure 1). Moreover, during the same period, the control group, although they did not take denosumab, showed an increase in the median TTR from $68 \%$ to $74 \%$, while the 25 th and 75 th percentiles did not show any significant variation (Figure 2). 


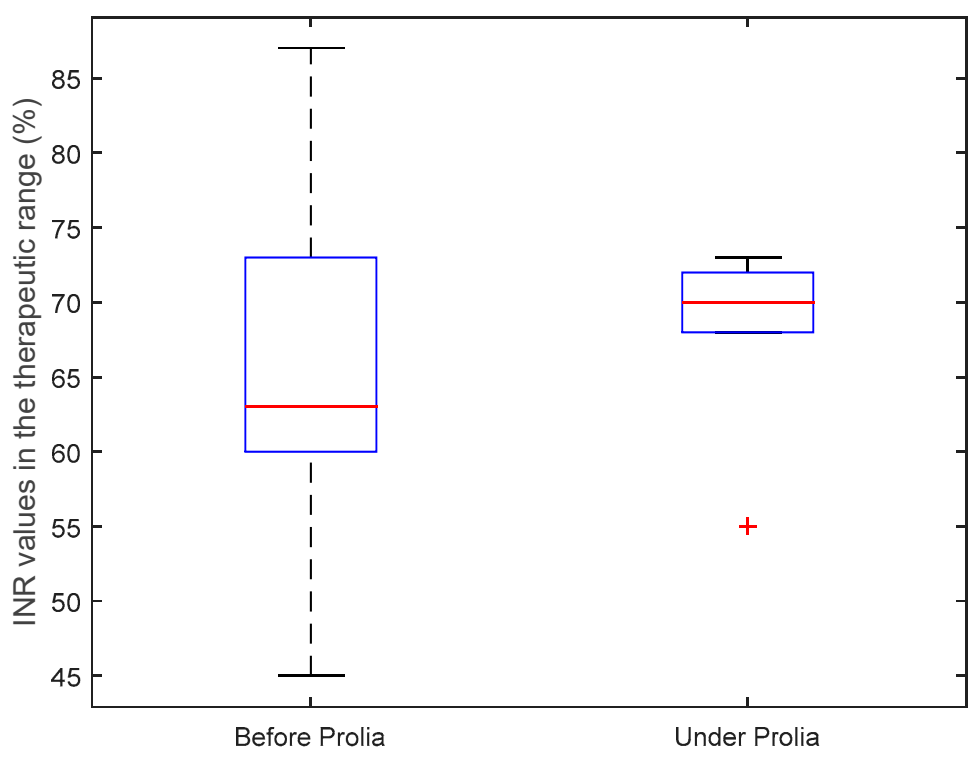

Figure 1. Comparison of the Prothrombin Time International Normalized Ratio (INR) value percentages in the therapeutic range before and during treatment with denosumab related to the patient group. The central mark in each box represents the median, the edges of the box represent the 25th and 75th percentiles, and the whiskers extend to the most extreme data points not considered as outliers.

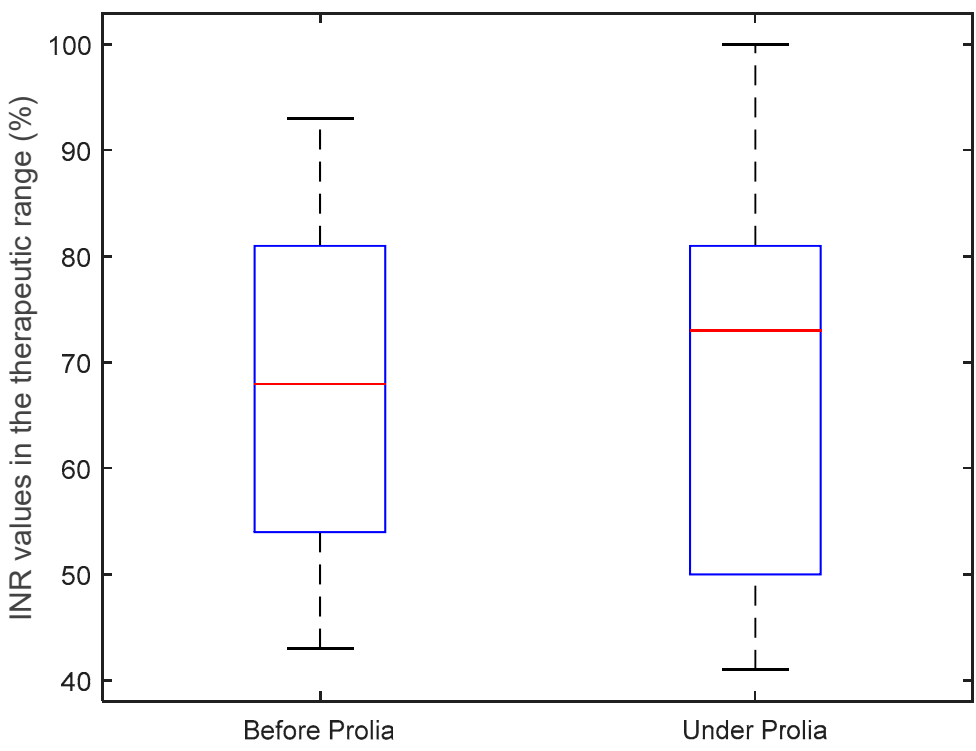

Figure 2. Comparison between INR value percentages of patients undergoing Warfarin therapy only and INR percentages in patients treated with Warfarin and denosumab. The central mark in each box represents the median, the edges of the box represent the 25th and 75th percentiles, and the whiskers extend to the most extreme data points not considered as outliers.

\section{Discussion}

Treatment with denosumab did not determine any significant variations in the TTR between the group of patients treated with both drugs and the group of patients who were taking only warfarin. This showed that the use of denosumab does not interfere with the metabolic processes which regulate the absorption and efficacy of warfarin and therefore its assumption does not require, in the case of therapy with denosumab, additional coagulation tests to verify the maintenance of the INR in the TTR. 
Author Contributions: Conceptualization, V.P. and G.S.; Methodology, G.S.; Formal Analysis, N.M.; Investigation, G.S. and F.B.; Data Curation, F.B.; Writing-Original Draft Preparation, F.B. and G.S.; Writing-Review and Editing, G.S.; Supervision, A.P.; Project Administration, A.P.

Conflicts of Interest: The authors declare no conflict of interest.

\section{References}

1. Yusuf, A.A.; Cummings, S.R.; Watts, N.B.; Feudjo, M.T.; Sprafka, J.M.; Zhou, J.; Guo, H.; Balasubramanian, A.; Cooper, C. Real-world effectiveness ofosteoporosis therapies for fracture reduction in post-menopausal women. Arch Osteoporos. 2018, 13, 33. [CrossRef] [PubMed]

2. Cairoli, E.; Palmieri, S.; Goggi, G.; Roggero, L.; Arosio, M.; Chiodini, I.; Eller-Vainicher, C. Denosumab or oral bisphosphonates in primary osteoporosis: A "real-life" study. J. Endocrinol Investig. 2018, 41, 1005-1013. [CrossRef] [PubMed]

3. Tanaka, Y.; Ohira, T. Mechanisms and therapeutic targets for bone damage in rheumatoid arthritis, in particular the RANK-RANKL system. Curr. Opin. Pharmacol. 2018, 40, 110-119. [CrossRef] [PubMed]

4. Gateman, D.; Trojnar, M.E.; Agarwal, G. Time in therapeutic range: Warfarin anticoagulation for atrial fibrillation in a community-based practice. Can. Fam. Physician 2017, 63, e425-e431. [PubMed]

5. Beaudoin, C.; Jean, S.; Bessette, L.; Ste-Marie, L.G.; Moore, L.; Brown, J.P. Denosumab compared to other treatments to prevent or treat osteoporosis in individuals at risk of fracture: A systematic review and meta-analysis. Osteoporos. Int. 2016, 27, 2835-2844. [CrossRef] [PubMed]

6. Ibrahim, S.; Jespersen, J.; Poller, L. The clinical evaluation of International Normalized Ratio variability and control in conventional oral anticoagulant administration by use of the variance growth rate. J. Thromb. Haemost. 2013, 11, 1540-1546. [CrossRef] [PubMed]

7. Moen, M.D.; Keam, S.J. Denosumab: A review of its use in the treatment of postmenopausal osteoporosis. Drugs Aging 2011, 28, 63-82. [CrossRef] [PubMed]

8. Vranckx, P.; Valgimigli, M.; Heidbuchel, H. The Significance of Drug-Drug and Drug-Food Interactions of Oral Anticoagulation. Arrhythm. Electrophysiol. Rev. 2018, 7, 55-61. [CrossRef] [PubMed]

(C) 2018 by the authors. Licensee MDPI, Basel, Switzerland. This article is an open access article distributed under the terms and conditions of the Creative Commons Attribution (CC BY) license (http://creativecommons.org/licenses/by/4.0/). 